\title{
Como sobreviver ao cinismo dominante no campo da saúde?
}

\author{
Francisco Romão Ferreira \\ Universidade do Estado do Rio de Janeiro, Instituto de \\ Nutrição, Programa de Pós-Graduação em Alimentação, \\ Nutrição e Saúde, Rio de Janeiro, RJ, Brasil. \\ <fromao@terra.com.br>
}

DOI: http://dx.doi.org/10.1590/1981-7746-sol00118

CASTIEL, Luis D.; XAVIER, Caco; MORAES, Danielle R. À procura de um mundo melhor: apontamentos sobre o cinismo em saúde. Rio de Janeiro: Editora Fiocruz, 2016, 400 p.

No livro À procura de um mundo melhor: apontamentos sobre o cinismo em saúde, os autores colocam o leitor diante de duas visões de mundo diametralmente opostas: de um lado, apresentam o cinismo vulgar da sociedade contemporânea com a sua lógica mercantil, pragmática e instrumental; e, do outro lado, apresentam a tradição do pensamento grego representada pelos filósofos cínicos da era helenística, ou melhor, apresentam o kinismo como um antídoto para o cinismo atual. Estamos vivendo uma época de exacerbação dos diferentes estilos deste cinismo vulgar - político, econômico, moral e acadêmico. É preciso então criar defesas e modos de entender esses tempos sombrios na esperança de encontrar uma luz ou uma saída. Neste sentido, o livro nos coloca diante de um impasse: Como sobreviver ao cinismo dominante no campo da saúde sendo ele hegemônico, altamente racional e coerente na sua lógica interna?

O cinismo vigente possui um discurso muito bem articulado e baseado em evidências comprovadas cientificamente, mas não consegue esconder a sua verdadeira face reacionária, excludente, preconceituosa e opressora. E o livro põe o leitor diante dessas duas imagens, como num espelho, no qual podemos criar uma ilusão de realidade ao ver alegria, juventude e beleza onde só existem decadência e exploração, ao ver a face agradável da tecnologia para não entrar em contato com a realidade da exploração econômica. É um retrato da nossa sociedade com sua imagem da felicidade eterna das redes sociais enquanto grassa o desemprego, a exclusão, o preconceito e a homofobia.

Este é um artigo publicado em acesso aberto sob uma licença Creative Commons.
Trata-se então de uma escolha como aquela do

filme Matrix - você pode ver o mundo como ele 
é (com toda a carga de angústia que a realidade apresenta) ou pode viver a irrealidade da felicidade eterna, sem riscos, sem rugas e sem contato com a interioridade. Uma felicidade mantida graças às maravilhas da tecnologia dos fármacos que produzem uma sociedade entorpecida, anestesiada e feliz.

O senso comum vê o cínico como um sujeito que afronta as normas sociais e as conveniências morais, agindo única e exclusivamente segundo o seu interesse imediato, sem pudor ou vergonha, de modo debochado e sarcástico, desprezando as regras da sociabilidade. Trata-se de um sujeito sem escrúpulos, petulante, atrevido, hipócrita e fingido. O cinismo em saúde, da mesma forma, se apresenta como uma solução tecnológica cientificamente comprovada, baseada em evidências, com o respaldo da comunidade científica e com todo o poder de sedução das mídias, da publicidade e das estratégias de comunicação da indústria farmacêutica. Nesta perspectiva, para todo mal (físico ou existencial) há um fármaco adequado, basta encontrá-lo e "seus problemas acabaram". O cinismo, o sarcasmo e o deboche aparecem nas campanhas publicitárias para melhorar a performance e garantir a felicidade eterna na "melhor idade". Elas beiram o escárnio. São tecnologias "de ponta" que proporcionam felicidade e juventude eternas, tudo sem dor, sem angústia e sem sofrimento.

Desde a arte estatuária grega, existe a busca por uma beleza ideal inatingível no plano humano. Essas esculturas simbolizariam uma espiritualidade que não pode ser 'contaminada' por traços que possam denunciar a presença da animalidade que há em nós, ou a passagem do tempo. O corpo da estatuária não é real, é pura idealização, e nele não aparecem as limitações do humano e os rastros da natureza física são retirados. A escultura grega elimina todos os vestígios do humano. Ela não tem rugas que indiquem a passagem do tempo, pelos que indicam a animalidade, veias que denunciam a passagem do sangue, dentes que lembram nossa gula e a natureza humana. Os detalhes que denunciam a animalidade e a finitude são retirados. Alguns setores das ciências médicas, da mesma forma, prometem um corpo jovem, belo e sem as angústias que são demasiado humanas. O cinismo em saúde parece resgatar esta promessa de um corpo ideal livre da passagem do tempo, da animalidade e dos sofrimentos e questionamentos naturais da vida, geralmente sem muito esforço por parte do cliente, basta adquirir o fármaco adequado. O cientificismo de alguns setores das ciências médicas, a mitologia da ciência, a hipocrisia dos discursos e a ideologia do mercado aparecem de forma clara e cristalina, desde que o sujeito queira ver.

Para enfrentarmos o cinismo atual vamos então conhecer o kinismo na versão grega que nos é apresentada com muita clareza e profundidade pelos autores. Eles conseguem expor o cinismo e a irrealidade do mundo contemporâneo, tendo como pano de fundo a realidade brasileira com suas artimanhas discursivas de alegria, felicidade, igualdade e cordialidade.

O precursor do Cinismo grego foi Antístenes, mas o seu principal representante foi o filósofo Diógenes de Sínope que, segundo a tradição filosófica, andava pelas ruas de Atenas com uma lanterna acesa em plena luz do dia fazendo uma pergunta prosaica: 'Como/onde encontrar um homem feliz?'

Ele procurava um homem que vivesse sua vida superando as exterioridades exigidas pelas convenções sociais como comportamento, dinheiro, luxo ou conforto material. Buscava um homem que tivesse encontrado a sua verdadeira natureza, que vivesse conforme ela e que fosse feliz sem ter que obedecer às normas sociais. A felicidade deste homem estaria numa vida simples e natural, sem precisar das comodidades da riqueza, do luxo, da ostentação e do apego às normas sociais. Com sua pergunta irônica Diógenes colocava em questão o que seria a vida de um homem segundo a sua mais autêntica essência, o que seria mais verdadeiro na existência, o que iria além de toda a exterioridade, das falsas aparências, dos caprichos da sorte de modo a encontrar sua verdadeira natureza e, quem sabe, viver de acordo com os seus valores mais essenciais para, simplesmente, ser feliz.

Se andássemos pelas ruas do Rio de Janeiro fazendo a mesma pergunta hoje, provavelmente encontraríamos como resposta que o homem feliz é rico, bem-sucedido, famoso, alto, musculoso, com porte atlético e, principalmente, magro. Em tempos de lipofobia e de estigmatização da gordura, a magreza se transformou em qualidade moral e parâmetro de felicidade. Ou seja, os homens felizes de hoje, necessariamente, estariam devidamente adaptados às convenções sociais, muito preocupados com a imagem corporal e social e nem saberiam dizer muito bem o que seria ou onde estaria a sua essência, sua verdadeira 
natureza. Assim como o personagem Dorian Grey (Wilde, 2014), do escritor irlandês Oscar Wilde, a preocupação com a beleza, com a imagem social e com uma vida marcada pelo hedonismo seriam as únicas marcas da existência, colocando a satisfação dos prazeres imediatos no lugar do sentido da vida. E se a vida não proporcionar a felicidade prometida não há problema, a indústria farmacêutica terá uma imensa variedade de produtos para resolver a falta de desejo, a fadiga, as rugas, o estresse, a tristeza, a depressão, a velhice, a reposição hormonal e a incapacidade de concentração, sem contar com as próteses e cirurgias estéticas.

Este homem supostamente feliz seria um cínico, um sujeito dissimulado, e sua felicidade seria medida em posts, likes, acessos e curtidas nas redes sociais. $O$ sentido da vida estaria na construção da imagem, na adaptação cega às normas e convenções sociais, criando um corpo sem alma, reproduzindo uma vida que desconhece a própria essência, vivendo uma existência sem sentido e sem interioridade, pura aparência. $O$ homem feliz seria, necessariamente, um metrossexual cheio de seguidores. O problema é que, assim como no retrato de Dorian Grey, a realidade teima em aparecer e os fármacos e as próteses da existência tendem a mostrar o lado ridículo do personagem.

O livro À procura de um mundo melhor: apontamentos sobre o cinismo em saúde apresenta então uma série de temas para discussão e reflexão que apontam para as nossas escolhas diante do crescimento desta onda hipócrita e conservadora. O leitor se vê também diante do espelho e não dá para ficar neutro ou indiferente às estratégias discursivas dos representantes do cinismo em saúde. São temas que discutem as estratégias de "aperfeiçoamento farmacológico" que levam ao sucesso acadêmico, os casos de doping que burlam o sistema e as estratégias discursivas que traduzem a ideologia científica atual. Os autores discutem também as formas como os parâmetros de beleza, magreza, juventude e vigor como exemplos de saúde ou de vida saudável e desejável, moralizando as condutas e controlando os comportamentos considerados desviantes ou de risco, sempre em nome do pragmatismo, da racionalidade da ciência e da objetividade.
A hiperprevenção e o automonitoramento aparecem como estratégias racionais e objetivas, frutos das escolhas livres e individuais dos sujeitos, sem mostrar que essas estratégias apequenam a vida, transformam sujeitos em coisas. A espetacularização da vida cotidiana transforma a existência numa performance que assegura a valorização de uma imagem social baseada no dinheiro, no sucesso a qualquer preço e numa felicidade prêt-à-porter.

Diante da proliferação de enunciados cínicos no campo da saúde só nos resta apelar aos kínicos, resgatando a ironia e o sarcasmo de Diógenes diante da hegemonia da 'racionalidade científica' e do pragmatismo utilitarista que coloca a vida a serviço dos interesses deste ambiente neoliberal conservador. Se toda época precisa de um Diógenes, encontramos neste livro uma postura típica dessa verve libertária que se apresenta de forma quase quixotesca diante da opressão do mercado, dos interesses da indústria farmacêutica e dos cínicos das ciências da saúde. Segundo os autores, em certa ocasião, Diógenes foi capturado por Felipe da Macedônia e, quando perguntado acerca da sua identidade, respondeu: "Sou um observador da sua insaciável ambição". Esta frase retrata fielmente o espírito do livro ao firmar que “não há melhor imagem do papel e da função do filósofo kínico no mundo: instalado em frente aos poderes constituídos, corajosamente dizendo o que é preciso dizer" (p. 53). Este livro, portanto, é um antídoto para tratar os males do cinismo e da hipocrisia, trazendo a parrhesia, a liberdade da palavra, como remédio para mostrar a desfaçatez e a arrogância dos cínicos que trabalham na sala ao lado.

\section{Referências}

WILDE, Oscar. O retrato de Dorian Gray. São Paulo: Ed. Landmark, 2014.

(cc) BY Este é um artigo publicado em acesso aberto sob uma licença Creative Commons. 
